\title{
FÖRÄNDERLIGT OCH OFÖRÄNDERLIGT INOM STRAFFRÄTTENS ALLMÄNNA LÄROR
}

\author{
AV PROFESSOR, JURIS DR. PER OLE TRÄSKMAN
}

The General Part of the penal law is discussed from a recent historical and comparative perspective. As the provisions in the General Part delimit the conditions for convictions, they are necessary supplements to penal provisions concerning the criminalization of a certain act (offence). Disagreements exist about the permanence and the international unity of these general provisions. As for the development of the General Part, it is assumed that the conditions and reflections influencing criminal policy in general also influence innovations of the provisions included in the General Part. The rationality and humanity of these reflections can be discussed, as can the extent to which the General Part reflects emotional and even populist perceptions.

For a long time, the General Part of the penal law has been limited to areas of legal practice and jurisprudence. In some countries, however, the General Part has recently become one of the primary issues of debate among legislators. Finland is an example of this.

Various circumstances shaping the changes of the General Part are discussed. Among these are circumstances related to penal ideology stating that the penal system is founded on blaming, questions of defining the subject who can be blamed (only a natural person, or moral persons or collectives), accentuation of the importance of international human rights, endeavours for international harmonization, and the economy of legal procedure.

Finally, trends within some specific areas of the General Part are discussed. These include the definition of an act, the question of penal jurisdiction, criminalization of preparation, attempt and conspiracy, criminalization of participation, reasons for excluding grounds of legal justification or guilt, prescription, and the measurement of sentences.

\section{Inledning: Vad skall vi göra med de allmänna lärorna?}

En finsk straffrättsprofessor, Reino Ellilä, har en gång karaktäriserat kriminalrätten genom att ange att den innehåller brottsrekvisitens katalog och reaktionsmedlens arsenal, samt de mer precisa villkoren för reaktionerna. ${ }^{1}$

\footnotetext{
* Title in English: Changing and Unchanging Issues of the General Part of the Penal Law. Original in Swedish.

${ }^{1}$ Reino Ellilä: Rikosoikeustieteen tehtävä ja suhde muihin tieteisiin. Lakimies 1960, s 937-943.
} 
Straffrättens allmänna läror anger de närmare villkoren för utdömande av straffansvar. De bestämmelser som finns inom denna del av straffrätten bildar ett genomgående stråk inom de normer som anger vad som är kriminaliserat. De enskilda kriminaliseringarna som uttrycks i gärningsbeskrivningen för ett visst delikt (straffbud) gäller vanligen bara en viss bestämd gärning. ${ }^{2}$ Då straffansvar utdöms i en fällande brottmålsdom fastställer domaren emellertid inte bara att en viss bestämd gärning utgör ett brott, utan samtidigt fastställer han också ett ansvar för den anklagade. I tillägg till beskrivningen av den enskilda gärningen som är straffbelagd, förutsätter systemet för straffansvar också vissa regler som anger grunderna för straffansvar. Det är dessa villkor för straffansvar som uttrycks i det som kallas straffrättens allmänna läror.

Vad som skall anses ingå i straffrättens allmänna läror, och hur området för de allmänna lärorna skall struktureras, är inte en gång för alla givet. Hur en sådan systematisering görs beror naturligtvis på många omständigheter, sådana som straffsystemets allmänna uppbyggnad, bakomliggande straffrättsliga ideologier, straffrättsteoretiska uppfattningar, avsikten med systematiseringen etc. Utan att närmare redogöra för mina skäl beskriver jag här de allmänna lärorna för brott genom att ange att de innehåller:

(a) Vissa allmänna villkor för att fråga skall vara om en straffrättsligt sett rättsstridig gärning (framför allt kravet på gärningskontroll och gärningsculpa),

(b) Vissa regler som begränsar skyldigheten och ansvaret att bete sig på det sätt som kriminaliseringen anger med hänvisning till geografiska områden och vissa nationella överväganden (jurisdiktionsfrågor),

(c) Vissa regler som avgränsar ansvaret för en straffrättsligt sett rättstridig gärning till en viss personkrets (möjlighet att vara brottssubjekt, medverkan i brott), respektive till den kriminaliserade gärningens realiseringsgrad (förberedelse, stämpling, försök),

(d) Vissa regler som innebär att en gärning som i vanliga fall bestämts vara rättsstridig, i vissa undantagsfall skall bedömas vara rättsenlig (grunder som utesluter rättsstridigheten),

(e) Vissa regler som begränsar möjligheten att klandra en gärning med hänvisning till gärningsmannens personliga utveckling (barn, unga), eller psykiska förmåga i övrigt (psykiskt störda personer),

(f) Vissa regler som innebär att en gärning som vanligen kan klandras i vissa undantagsfall skall anses vara ursäktad (grunder som utesluter skuld)

(g) Vissa regler som innebär att straffansvar inte längre kan utdömas, framför allt på grund av preskription.

(h) Vissa regler som anger hur straffmätning och påföljdsval skall ske.

De allmänna lärorna uttrycker framför allt nödvändiga villkor för straffansvar. Man kan därför säga att de allmänna lärorna finns till för att fokusera det straffrättsliga ansvaret till de fall, då utdömande av straffansvar verkligen är be-

\footnotetext{
${ }^{2}$ Undantagsvis kan kriminaliseringen gälla serier av gärningar som konstituerar ett levnadssätt (t.ex. $\mathrm{BrB} 11$ kap. 3 §, vårdslöshet mot borgenärer), en verksamhet (t.ex. BrB 19 kap.10 §, olovlig underrättelseverksamhet) eller ett kontrollerat tillstånd (t.ex. Narkotikastrafflagen $\S 1$, innehav av narkotika).
} 
fogat och berättigat för att avhålla människor från ett visst beteende. Utformningen av de allmänna lärorna är central med tanke på hur väl straffsystemet uppfyller just den funktion som man utgår från att det har, nämligen att avhålla människorna från att begå vissa handlingar. ${ }^{3}$

Det är en truism att alla kriminaliseringar innefattar politiska beslut. Straffsystemets utformning och de mål som man önskar uppnå genom användningen av straff återspeglar alltid delar av den allmänna samhällspolitiken. Då den allmänna samhällspolitiken inte är oföränderlig, kan inte heller de delar av den som utgörs av kontrollpolitiken, kriminalpolitiken eller straffrättspolitiken vara det. Som en konsekvens av detta kan man också förvänta sig att de bestämmelser som ingår i straffrättens allmänna läror förändras. Också de skall vara sådana läror som är förenliga med "vår tid" och återspegla de uppfattningar som är "moderna" i det samhälle där de skall tillämpas. $^{4}$

Straffrätten karaktäriseras ibland som ett konservativt, "anakronistiskt" rättsområde. Straffrätten har kritiserats för att den inte håller jämna steg med den övriga samhällsutvecklingen. ${ }^{5}$ Man har sagt att strafflagarna borde totalrevideras vart femte år. Vad som behövs är avstämningar i två riktningar, nämligen både avkriminaliseringar eller nedkriminaliseringar och nykriminaliseringar eller uppkriminaliseringar. ${ }^{6} \mathrm{Om}$ detta synsätt är riktigt borde också straffrättens allmänna läror utvisa ganska betydande förändringar redan inom ett kortare tidsperspektiv.

Straffrätten har ofta också karaktäriserats som ett mycket nationellt rättsområde. Detta förklaras vanligen med straffrättens starka bindning till respektive stats nationalpolitik. Det har pekats på att ett visst samhälle i stor utsträckning kan bedömas just med stöd av dess strafflagstiftning. ${ }^{8}$ Nils Christie har konstaterat att

\footnotetext{
3. Se t.ex. Nils Jareborg: Allmän kriminalrätt. Uppsala 2001, s 45- 65.

${ }^{4}$ Att kriminalpolitiken utgör en integrerad del av den allmänna samhällspolitiken betonades starkt $\mathrm{i}$ den kriminalpoltiska debatten och den kriminalvetenskapliga forskningen under 1970-talet - i de nordiska länderna särskilt i Finland. Se bl.a. Inkeri Anttila - Olavi Heinonen - Pekka Koskinen - Raimo Lahti: Rikollisuus ongelmana. Helsinki 1974, s. 114-115. Se också (i viss mån problematiserande): Vagn Greve: Det strafferetlige ansvar. København 1999, s 1-19.

5 "Straffrättsforskningen måste alltid "följa med tiden". Den måste anpassas till den ekonomiska och tekniska utvecklingen, och den måste vara internationell. Intresset av att grunna på hur en svensk vallgosse skall straffas för tidelag (detta var 1700-talets stora kriminalpolitiska fråga) är idag betydligt mindre än t ex en analys av om, och hur den internationella miljöförstöringen kan förhindras genom straffrättsliga medel. De rätta gränserna för straffrätten är inte en gång för alltid givna, utan de måste ständigt omprövas." Per Ole Träskman. Lunds universitet Professorinstallation 8/3.96. VIII.

${ }^{6}$ Inkeri-Anttila - Olavi Heinonen: Rikos ja seuraamus. Rikosoikeuden perusteet. Helsinki 1971, s. 15-16.

${ }^{7}$ Bl.a. Per Ole Träskman: Den internationella straffrätten. Raimo Lahti (toim.): Nykyajan rikosoikeus II. Rikosoikeuden julkaisuja 4. Helsingin yliopisto. Rikos- ja prosessioikeuden sekä oikeuden yleistieteiden laitos. Helsinki 1997, s 317-343.

${ }^{8}$ Se också Britta Kyvsgaard: Den samhälleliga polariseringen och oskadliggörandet av lagöverträdare. Dag Victor (red.): Varning för straff. Om vådan av den nyttiga straffrätten. Stockholm 1995, s 110-136.
} 
Straffeappartet bærer med seg viktige budskap om samfunnstilstanden. Intet sa oss mer om Tyskland under Hitler, om Russland under Lenin og Stalin, eller om Kina under Mao, enn hvordan de kontrollerte og straffet sine borger. ... Målt mot våre generelle verdier bliver vi i enkelte tilfeller i stand til at si at det er noe fundamental galt med enkelte statssystem. Omvendt kan vi komme til å si: Her er noe fint, bevaringsverdig, hva ligger mon tro bakom disse gode tilstander? ${ }^{9}$

Men samtidigt har man också konstaterat att särskilt de allmänna grunderna för fastställande av straffansvar är tämligen generella och i stor utsträckning gemensamma, åtminstone i stater som finns inom samma kulturkrets. Det är sådana uppfattningar som ofta lägger grunden t.ex. för de strävanden som finns för att harmonisera eller uniformera straffrätten inom Europeiska unionen. ${ }^{10}$ Det kan emellertid noteras att uppfattningen om kriminalrättens internationella grundkaraktär inte är ny. Vid sin granskning av förslaget till ny strafflag för Finland 1879 konstaterade Uppsalaprofessorn Johan Hagströmer bl.a. att

Långt mer än någon annan del af den allmänna rätten eger straffrätten i våra dagar en kosmopolitisk karaktär. Genom de senaste årtiondenas lagstiftning hafva de internationella olikheterna på detta område i många delar blifvit utjämnade, och de stora legislativa arbeten, hvarmed man för närvarande i flera land är sysselsatt, gå afgjort i samma riktning. Denna utveckling innebär rika löften för straffrättens framtid. ${ }^{11}$

Men hur kommer bestämmelserna i straffrättens allmänna läror egentligen till - vad är det som styr deras utformning. Huvudsakligen måste det vara samma typ av omständigheter och överväganden som påverkar de kriminalpolitiska besluten i allmänhet, som avgör utformningen av de allmänna lärorna. Det betyder att man vid en beskrivning av straffrättens allmänna läror, och den utveckling som skett inom dem, lätt kommer att använda sådan generell karaktäristik som hänvisar till tidsenlighet ("modern"), förnuftsmässighet ("rationell"), mänsklighet ("human") och rättvisa ("socialt rättvis"). På ett teoretiskt plan vill vi väldigt gärna se straffrätten som modern, humanistisk och socialt rättvis, och beskriva den som ett verktyg som lyckas förmedla det klander som straffen skall förmedla på ett kontrollerat och välmotiverat sätt. ${ }^{12}$ I praktiken blir det ofta annorlunda än vad denna idealbild visar: de kriminalpolitiska besluten ger inte sällan uttryck för irrationalitet, emotionalitet och populism. ${ }^{13}$ Ett konstant

\footnotetext{
${ }^{9}$ Nils Christie: En passende mengde kriminalitet. Oslo 2003, s. 126.

${ }^{10}$ Per Ole Träskman: Strafflagen för Europeiska Unionen - Fakta och fiktion. SvJT 2002, s 345-362. Se också Kimmo Nuotio: On the Significance of Criminal Justice for a Europe 'United in Diversity". Kimmo Nuotio (Ed.): Europe in Search of "Meaning and Purpose". Helsinki 2004, s171-210.

${ }^{11}$ Johan Hagströmer: Granskning af Förslaget till strafflag för Storfurstendömet Finland. Upsala 1879, s. 1.

${ }^{12}$ Se Raimo Lahti, t.ex.: Towards a Rational and Humane Criminal Policy - Trends in Scandinavian Penal Thinking. Journal of Scandinavian Studies in Criminology and Crime Prevention. Vol. 1 (2000), s 141-155. ${ }^{13}$ Se Per Ole Träskman och Britta Kyvsgaard: Vem eller vad styr straffrättspolitiken? Flores juris et legum. Festskrift till Nils Jareborg. Uppsala 2003, s 607-636, särskilt s 635-636. Dag Victor har beskrivit delar av den kriminalpolitiska debatten i Sverige på följande sätt: "Och retoriken kan inte avvisas som innehållslös. Den rymmer kunskapsförakt, anti-intellektualism och brist för förståelse för traditionella rättsstatliga principer. Det kan knappast uppfattas som en tillfällighet när en svensk justitieminister avfärdar vidare diskussion
} 
tema i den kriminalpolitiska debatten och i den kriminalvetenskapliga diskussionen har varit frågan om hur rationellt eller emotionellt det kriminalpolitiska beslutsfattandet egentligen är - eller skall vara.

Jag nöjer mig med att beskriva detta genom några citat som hänför sig till några nordiska kriminalvetenskapliga forskare som representerar skilda tidsåldrar och skilda skolor:

Enligt sin natur och sitt väsen bör ...rätten hafva gifvit sig ett uttryck i statens lagar, den bör vara hvad man kallar positiv. [...] Det är visserligen sant att den positiva rätten ingenstädes fullt ut motsvarar hvad det begreppsenligt rätta strängt taget skulle fordra, likasom företeelserna $\mathrm{i}$ världen öfver hufvud $\mathrm{i}$ högre eller lägre grad afvika från det som begreppsenligt borde vara fallet. Dessa större eller mindre afvikelser bero på mångfaldiga i den yttre världen förekommande omständigheter. Kunde vi tänka oss en idealstat, hvilket sedan gamla tider utgjort en dröm, vore äfven en dylik enligt det rena rättsbegreppet formerad lagstiftning tänkbar. Men idealstaten är såsom kändt, en dröm, och därför är äfven en positiv rätt, som vore i öfverenstämmelse med blott teori och vetenskap, en dröm. Det vore i sjäfva verket ett vådligt misstag att söka konstruera ett folks positiva rätt uteslutande med ledning av den vetenskapliga teorin. Ty hvarje positiv rätt måste vara uttryck af nationens rättsmedvetande, och detta rättsmedvetande, som sålunda är för den positiva rätten bestämmande, är en produkt af oändligt många i den konkreta värkligheten existerande faktorer, hvilka hafva sin rot i folkets kultur och historiska utveckling. ${ }^{14}$

Det er en selvfølge, at en rationel kriminalpolitik må være baseret på en korrekt opfattelse af omverdenen og af de samfundsmæssige sammenhænge. Man må anvænde statistiske beskrivelser, sociologisk teori o.s.v. eller med andre ord de empiriske videnskabers resultater. Det er ikke detsamme som, at kriminalpolitik kun kan baseres på veldokumenterede undersøgelsesresultater. På mange områder findes ikke sådanne, og retspolitikeren må i så fald nøjes med mere løse skøn og gisninger, som ikke er efterprøvet - og måske ikke kan efterprøves - på et videnskabeligt set forsvarlig måde. ${ }^{15}$

Innenfor de grenser som følger av [...] overordnede rettskildefaktorene, står lovgiveren rettsligt fritt til å vedta en hvilken som helst regel om straff. Og domstolene står fritt til å treffe avgjørelser innefor de grenser som lovgiveren har gitt dem. Men bruken av denne friheten styres i stor utsrekning av kulturelle verdier, som ved tolkningen av straffelovgivningen har status som reelle hensyn ... De kulturelle verdierne i det norske samfunnet utgjør derfor også kjernen i strafferetten. ${ }^{16}$

För den som väljer att begå brott och riskerar att straffas härför, kan straffet ses som ett pris som han eller hon kan få betala för den tillfredsställelse eller det utbyte som utförandet av brottet givit. Härav följder att det inte är uteslutet, att det från den enskildes synpunkt är rationellt att begå brott (särskilt som upptäcktsrisken ofta är ganska liten). Häri ligger till

om individualpreventiva effekter med orden att "Ni Har Er tro och jag har min". Dag Victor: Politik och straffsystem - ett drama under utveckling. Dag Victor (red.): Varning för straff. Om vådan av den nyttiga straffrätten. Stockholm 1995, s. 57 - 78.

${ }^{14}$ Jaakko Forsman: Anteckningar enligt professor Jaakko Forsmans föreläsningar öfver straffrättens allmänna läror med särskild hänsyn till strafflagen af den 19 december 1889. Med tillstånd af föreläsaren utgifna af Lars Wasastjerna. Tredje upplagan. Helsingfors 1930, s. 2-3.

${ }^{15}$ Greve (1999) s.28.

${ }^{16}$ Ståle Eskeland: Strafferett. Oslo 2000, s.52-53. 
någon del förklaringen till varför det är så vanligt, att även s.k. vanliga, hederliga människor förövar småbrott. För många är det så att brott lönar sig. En merkantil inställning till straff har den fördelen att den implicerar - förutom att bestraffning är rättvis - att saken är utagerad när straffet är verkställt. Härigenom motverkas den stigmatisering som ofta drabbar den som avtjänat ett frihetsstraff. $\AA$ andra sidan får dock pristänkandet inte drivas så långt att straff likaställs med avgifter. I bestraffningen måste ligga ett centralt element av klander som inte finns vid andra samhällsingripanden. ${ }^{17}$

Ved evalueringen av et lands straffesystem kan det være hjelpsomt å se på fire sentrale trekk: For det første, de typer lovbrudd som det reageres imot innefor statsdannelsen. Noen stater straffer handlinger som mange blant oss mener burde gå upåtalt hen, eller til og med burde vært høyt verdsatt Her kommer selvfølgeligt spørgsmålet om politisk, religiøs og kulturell opposisjon inn i bildet.

For det annet, de former avgjørelsene om straff fattes innen. [...]

For det tredje reiser seg et spørgsmål om hvem som bliver straffens mottakere. Spesielt: Hvor representative er disse for befolkningen i sin alminnelighet når det gjelder alder, kjønn, klasse og rase? Et ekstremt skjevt rekruttert utvalg af straffede kan gi mistanke om utilfredsstillende tilstander innefor systemet.

For det fjerde kommer spørgsmålet om mengde og former for straff. $[\ldots]^{18}$

Ett annat bestående tema i den kriminalpolitiska och den kriminalvetenskapliga debatten har varit hur explicit och precist utformade bestämmelserna inom straffrättens allmänna läror egentligen skall vara utformade. Ofta har man ansett att dessa bestämmelser skall förbli oskrivna och placeras utanför det område som lagstiftaren bestämmer om. ${ }^{19}$ Detta har ibland motiverats med bristen på kunskap, med uppfattningarnas föränderlighet och lagstiftarens oförmåga att formulera den rätta regeln och ibland med kravet på stor flexibilitet. Rättsvetenskapen och rättspraxis har ansetts vara bättre lämpade att formulera bestämmelserna inom straffrättens allmänna läror på ett sådant sätt att de vid var tid svarar mot deras grundläggande syfte, d.v.s. att finna fram till rätt person (den person som skall klandras för en brottslig gärning) och att fastställa detta klander på ett sätt som just vid den tidpunkten framstår som det riktiga. ${ }^{20}$

Det förnuftiga i att bibehålla bestämmelserna i straffrättens allmänna del oskrivna med tanke på att alltid kunna tillgodogöra sig forskningens nya landvinningar betonades starkt av Hagströmer i hans granskning 1879 av förslaget till ny finsk strafflag:

\footnotetext{
${ }^{17}$ Jareborg (2001), s 62-64.

${ }^{18}$ Christie (2003), s 126-127.

${ }^{19}$ Se också prop. 2000/01:85 (Sverige), särskilt avsnitt 4.

${ }^{20}$ Straffrätten skiljer sig från andra rättsområden genom användning av klander. Bl.a. Jareborg [(2001), s 62-64] betonar starkt just detta klander. "I bestraffningen måste ligga ett centralt element av klander som inte finns vid andra samhällsingripanden. På motsvarande sätt von Hirsch: Bestraffning ger uttryck för klander. Skillnaden mellan skatt och ett bötesstraff ligger inte i vad någon berövas ... utan i det förhållandet att ett bötesstraff, i motsats till beskattning, förmedlar ogillande och klander. Andrew von Hirsch: Proportionalitet och straffbestämmning. Juridiska fakulteten i Uppsala. Årsbok 2001. Uppsala 2001, s. 36-41.
} 
Vår tids straffrättsvetenskap utmärker sig ej genom något öfvermått af tillit till sin egen fullkomlighet och produktiva makt. Det ideal, hvartill den strävar, är ... : en på en gång enhetlig och alt omfattande systematisk tankebyggnad. Men man har lärt att inse, att detta ideala mål icke kan finnes så lätt, som man en gång antog. ... Och den nutida vetenskapen skyr ej att erkänna, att den ... långtifrån är så färdig med sitt arbete, som man för icke så länge sedan trodde sig vara. Frågor, med hvilka teorien då aktade under sin värdighet att närmare sysselsätta sig, hafva i vår tid gjorts till föremål för grundliga undersökningar, som ännu icke äro afslutade. I många delar af straffrätten är den gamla läran rubbad och grunden till en säker uppbyggnad ännu icke lagd. I andra delar har man uppenbarligen träffat sakernas rätta sammanhang, men de vunna sanningarna hafva ännu icke fått den skarpa formulering, som är nödvändig för att man skall kunna med säkerhet arbeta med dem. ${ }^{21}$

Det är intressant att se att samma grundton fortfarande är förhärskande då regeringen (snarast justitiedepartementet) i Sverige år 2000 avslog bl.a. förslaget $^{22}$ att $\mathrm{i}$ lagen inta en skriven bestämmelse om uppsåt.

Regeringens utgångspunkt vid en bedömning av de förslag som utredningen har presenterat är att man bör iaktta stor försiktighet när det gäller förändringar av sådana allmänna straffrättsliga regler som har ett vidsträckt tillämpningsområde. Till denna grupp av regler hör huvuddelen av de regler som utredningen behandlat, bl.a. reglerna om uppsåt, medverkan och försök. Ett skäl att iaktta en sådan försiktighet är att sådana regler måste ges en förhållandevis generell utformning och att den närmare innebörden av dem därför alltid måste preciseras i rättstillämpningen. Varje förändring av dessa allmänna, övergripande regler innebär ofrånkomligen att det under en inte obetydlig tidsperiod kommer att råda viss osäkerhet om den närmare innebörden av gällande rätt. För att det skall vara försvarligt att föreslå ändringar i regler som, genom utveckling i praxis och doktrin, kommit att få en relativt preciserad innebörd fordras därför att det finns ett påtagligt praktiskt eller rättspolitiskt behov av förändring. Ett sådant behov kan t.ex. bestå i att regleringen är ofullständig och, på ett sätt som inte är sakligt motiverat, innebär att klart straffvärda förfaranden inte är kriminaliserade, eller i att regleringen avviker från de rättssäkerhetskrav som bör upprätthållas.

Sammantaget kan sägas att de fördelar som kan stå att vinna med en förändring alltid måste vägas mot de nackdelar av nyss nämnt slag som förändringen medför. En annan utgångspunkt för regeringens bedömning är att förändringar av centrala straffrättsliga bestämmelser, som har ett vidsträckt tillämpningsområde, bör göras endast om konsekvenserna av ändringarna är genomlysta på ett tillfredsställande sätt. Eftersom regler av den typ som här diskuteras är tillämpliga i förhållande till en lång rad olika brottstyper, och följaktligen har stor betydelse för att avgränsa det straffbara området, torde ofta krävas en omfattande och ingående analys för att man skall kunna överblicka konsekvenserna av en ny reglering. ${ }^{23}$

Men det skall också noteras att den kritiska inställning till att i lagen inta skrivna bestämmelser om straffrättens allmänna läror har övergetts vid de totala strafflagsreformer som är aktuella i Finland och i Norge. ${ }^{24}$ Som en del av den

\footnotetext{
${ }^{21}$ Hagströmer (1879) s. 8-9.

${ }^{22}$ Förslaget fanns i kommittebetänkandet som avslutade Straffansvarsutredningens arbete. SOU 1996:185. Straffansvarets gränser.

${ }^{23}$ Prop.2000/01:85.

${ }^{24}$ Beträffande Norge, se Straffelovkommisjonens delutredningar, särskilt den senaste NOU 2002:4. Ny straffelov. Straffelovkommisjonens delutredning VII. De tidigare är: NOU 1983:57, NOU 1984:31, NOU 1989 11, NOU 1990:5, NOU 1992:23 och 1992:23.
} 
fullständiga revideringen av den finska strafflagen genomfördes också en revision som innebar att straffrättens allmänna läror i sin helhet fick en skriven form i gällande strafflag. ${ }^{25}$ Det står klart att skälen till detta inte överensstämmer med dem som finns i ovan citerade svenska ställningstagande. I den regeringsproposition som ledde till den finska lagändringen motiverades åtgärden på följande sätt:

[Gällande] lagstiftning[..] omfattar även många legaldefinitioner och begreppsbestämningar som förut ansågs falla utanför lagstiftarens kompetens. Det finns inga lagstiftningsteoretiska hinder mot att straffrättens allmänna läror kodifieras mer exakt än tidigare. Av kriminalpolitiska skäl är det däremot rent av nödvändigt att lagstiftaren vid beredningen av den nya strafflagen driver frågorna avsevärt längre än man har gjort hittills. Behovet att kodifiera de allmänna lärorna har sin grund i de krav som framför allt legalitets- eller laglighetsprincipen och rättsäkerheten ställer. Legalitetsprincipens betydelse inskränker sig inte bara till strafflagens särskilda del. Gränsen mellan straffbart och icke-straffbart beteende bestäms i sista hand utgående från begreppskategorierna i ansvarsläran. Med tanke på legalitetsprincipen är det viktigt att veta t.ex. när en handling är uppsåtlig i den mening som avses i strafflagen, under vilka förutsättningar underlåtenhet medför ansvar eller vilken inverkan okunnighet eller villfarelse har. Detta slags avgöranden blir domstolarna tvungna att fatta dagligen utan något stöd i lagstiftningen. Förslaget innehåller i själva verket en stor mängd bestämmelser som saknar motsvarighet i den gällande strafflagen. Det är frågan om det allmänna kravet på tillräknande, definitionerna av uppsåt och oaktsamhet, villkoren för underlåtenhetsansvar, reglerna om villfarelse och fördelningen av ansvar med anledning av brott som har begåtts i en juridisk persons verksamhet. Vidare har i stort sett alla ansvarsbestämmelser i den gällande strafflagen reviderats också innehållsligt. Reformen innebär således en omfattande kodifiering av de allmänna lärorna. ${ }^{26}$

En sammanfattning av det som jag anfört om vilken funktion straffrättens allmänna läror har, vilken karaktär de har, vilka faktorer det är som påverkar deras utformning, och i vilken form denna utformning skall uttryckas, kan göras i följande punkter:

- Straffrättens allmänna läror anger de närmare villkoren för utdömande av straffansvar. Härigenom utgör de en fullständigt nödvändig komplettering av de enskilda straffbuden.

- Det finns en oenighet om hur bestående och hur internationellt enhetliga straffrättens allmänna läror är - eller bör vara.

- Man kan anta att det är samma typ av omständigheter och överväganden som påverkar de kriminalpolitiska besluten i allmänhet som avgör utformningen av de allmänna lärorna. Det kan diskuteras hur rationella och humanitära dessa överväganden är, och i vilken utsträckning de allmänna lärorna är konsekvenser av emotionella eller t.o.m. populistiska uppfattningar.

- De allmänna lärorna har länge hänvisats till verksamhetsområdet för rättspraxis och rättsvetenskap. Den nyaste utvecklingen har dock (i vissa stater) flyttat de allmänna lärorna till att bli ett av lagstiftarens kärnområden.

\footnotetext{
${ }^{25}$ Se förf. 13.6.2003/515.

${ }^{26}$ Regeringens proposition 44/2002 rd. (Finland). Regeringens proposition till Riksdagen med förslag till revidering av lagstiftningen om straffrättens allmänna läror.
} 
Det följande steget i min granskning av straffrättens allmänna läror och deras utveckling blir att analysera vilka skäl det kan finnas bakom att lärorna utvecklas i en viss riktning, eller kvarstår som oförändrade.

\section{Fortsättning: Kontinuitet eller förändring - hur skall vi finna eller få straffrättens allmänna läror i deras rätta innehåll och i deras rätta form?}

Vilket innehåll straffrättens allmänna läror har bestäms av flera omständigheter. Skälen till att lärorna fått/får ett visst innehåll är varierande och långt ifrån likriktade. Skälen har en tämligen varierande bas och de slår primärt också igenom på skilda nivåer av det straffrättsliga systemet.

Man kan identifiera flera skäl till att de allmänna lärorna har en viss utformning. Utformningen har skett utgående från varierande hänsyn, sådana som moraliska, etiska, pragmatiska, emotionella, ideologiska, ekonomiska, rationella, reella skäl eller t.o.m. skäl som är "rent kosmetiska". De skäl som uppfattas vara relevanta får genomslag på straffsystemets skilda nivåer. Man kan skilja mellan skäl som gäller vid fastställande av straffansvar på lagstiftningsplanet (t.ex. vilka gärningar, förövade var och av vem skall kunna leda till straffansvar), och skäl för fastställande av straffansvar i ett enskilt fall (t.ex. hur skall det klander som riktas mot de personer som begått ett konkret brott fördelas just i detta fall - vem skall dömas som gärningsman, vem som medhjälpare).

Det finns också ett antal skäl för utformningen av straffrättens allmänna läror som till en väsentlig del bygger på processuella hänsyn. Hur skall de allmänna lärorna utformas för att i praktiken garantera ett rättvist avgörande med beaktande av möjligheterna till tillräcklig bevisning (d.v.s. en viss typ av rättviseskäl), ${ }^{27}$ hur skall de utformas för att garantera en tillräcklig effektivitet (effektivitetsskäl) ${ }^{28}$ och hur skall de utformas för att uppnå en optimal processekonomi (processekonomiska skäl; t.ex. hur kan man förenkla de materiella reglerna för att möjliggöra ett summariskt förfarande och samtidigt garantera ett fällande avgörande i tillräckligt många, men inte i felaktiga fall)?

Något mer konkretiserat innebär detta att vi kan granska straffrättens allmänna läror och den utveckling som har skett inom dem - med samtidig referens till kriminalpolitikens och straffrättspolitikens allmänna utvecklingslinjer - genom följande karaktäristik och följande exempel.

\footnotetext{
${ }^{27}$ Det är denna typ av skäl som jag fäster stor uppmärksamhet vid i en artikel där jag granskar uppsåtsbegreppet. Se Per Ole Träskman: Kan gärningspersonens uppsåt bevisas med hållpunkter i sinnevärlden? Nils Jareborg och Per Ole Träskman (Red.): Skuld och ansvar. Straffrättsliga studier tillägnade Alvar Nelson. Uppsala 1985, s 56-75.

${ }^{28}$ Lernestedt (2003), s 312-350; Per Ole Träskman: Straffrättens förutsättningar och begränsningar som styrmedel av miljöskadlig verksamhet. NTfK 2002, s 1-15; Thomas Elholm: Den Europeiske Unions harmonisering af strafferetten. NTfK 2002, s 77-105.
} 
Vi kan iaktta en betoning av att klander skall utgöra ett centralt element inom det moderna straffsystemet. Detta inbegriper också en utveckling från effektansvar till skuldansvar, från en betoning av gärningens följder till gärningsmannens intention, från gärningens effekt till gärningens farlighet. Vad som betonas är bl.a. klandrets likvärdighet vid brottstyper som konstruerats som effektbrott respektive farebrott, ${ }^{29}$ att uppsåtsbrott skall vara mer klandervärda än oaktsamhetsbrott, ${ }^{30}$ täckningsprincipens centrala betydelse, ${ }^{31}$ samt kravet på att den anklagade bör vara "en normal människa" med normal förmåga att anpassa sitt handlande till rättsordningens krav (konformitetskravet). ${ }^{32}$ Också skilda grunder som ursäktar en normalt sett kriminell handling får en stor betydelse. ${ }^{33}$

Vi kan också iaktta en betoningen av krav på social rättvisa, jämlikhet, och "lika behandling" trots människornas varierande resurser. Det finns ett uttalat intresse av att också straffrätten skall framstå som ett rättsområde som betonar samhällets sociala ansvar. ${ }^{34}$ Denna karaktäristik av straffrättsutvecklingen som socialt ansvarlig kan emellertid också ifrågasättas med hänvisning till ett antal konkreta exempel som knappast kan förenas med en "social straffrätt". ${ }^{35}$ Men åtminstone i vissa fall och på

${ }^{29}$ Se Kom.bet.1976:72. Straffrättskommittens betänkande. Helsingfors 1977, och Inkeri Anttila \& Patrik Törnudd: Dynamics of the Finnish Criminal Code Reform. Patrik Törnudd: Facts, Values and Visions. Essays in Criminology and Crime Policy. National Research Institute of Legal Policy. Helsinki 1996, s 137162, särskilt s 155-157. Se också Claes Lernestedt: Kriminalisering. Problem och principer. Uppsala 2003, s 181-248. Då det gäller farekriminaliseringar i stället för skadekriminaliseringar vid miljöbrott, se Träskman (2002), s 9-10.

${ }^{30}$ Nils Jareborg: Uppsåt och klander. Varför är ett uppsåtligt brott mer straffvärt än ett oaktsamt? Nils Jareborg: Straffrättsideologiska fragment. Uppsala 1992, s 173-205.

${ }^{31}$ Jareborg (2001), s 334-358.

${ }^{32}$ Beträffande konformitetsprincipen, se t.ex. Jareborg (2001), s 302-304.

${ }^{33}$ Detta gäller de traditionella "ursäktande grunderna" särskilt excess vid nödvärn. Några svenska rättsfall som förefaller att ge uttryck för en "ny form" för ursäkt kan nämnas. Det intressantaste av dem gäller en person som efter att han mottagit ett paket med för honom okänt innehåll, medan han förvarade paketet för ägarens räkning, kom underfund med att det innehöll en stor mängd heroin, undgick straffansvar för grovt narkotikabrott. Han överlämnade paketet till polisen först några dagar efter sin upptäckt av vad det innehöll. HD ansåg att den anklagade i detta fall hade rätt till "ett skäligt rådrum". HD konstaterade: "Därvid måste beaktas att de av honom (=den anklagade) berörda riskerna för att inte bli trodd av polisen och för att bli utsatt för repressalier får anses svara mot realiteter och att intressekonflikten ingalunda minskade genom att det rörde sig om en mycket stor mängd narkotika av särskilt farligt slag. Vid en samlad bedömning bör det dröjsmål med att ta kontakt med polisen som ligger honom till last inte skäligen leda till att han skall anses ha förövat en brottslig gärning." (HD Dom 25 september 2003, Mål nr B 4696-02). Det kan noteras att tingsrätten dömt den anklagade till 5 år fängelse och hovrätten till fyra månader fängelse.

${ }^{34}$ Når udgangspunktet tages i den sociale retfærdighed, føles det nærliggende at bruge strafferetten mod andre former for samfundsskadelige handlinger end den traditionelle kriminalitet (tyveri,vold o.s.v.), der forbindes med underklassen. Staten skal også strafbelægge og forfølge adfærd der begås af virksomheder og højstatuspersoner, f.eks. skattesvindel, konkursrytteri og miljøkriminalitet. Den indskrænker de stærke befolkningsgruppers individuelle frihesrettigheder for at beskytte svage medborgere. Greve (1999), s 10.

${ }^{35}$ Dessa exempel ligger huvudsakligen inom området för påföljdssystemet, där man kan iaktta en i och för sig positiv utveckling genom nya former av samhällsstraff (t.ex. samhällstjänst och intensiv övervakningen genom elektronisk kontroll) som dessvärre inte kan användas när den anklagade är socialt utslagen. Se 
vissa av straffrättens områden har man klart uttalat intentionen att de straffrättsliga normerna skall utformas så att de skyddar den svagare parten, ${ }^{36}$ eller visar tillbörlig respekt för genushänsyn. ${ }^{37}$

Vi kan vidare iaktta en utveckling som gäller frågan om straffansvaret skall fokuseras till en fysisk person, en juridisk person eller till ett kollektiv. Ett straffansvar för juridiska personer har införts eller befästs i majoriteten av de nordiska staterna, ${ }^{38}$ och närmast med anledning av internationella krav har man också övervägt att införa eller infört ett straffansvar för enskilda individer för gärningar som kan spåras till ett visst kollektiv med grund i att individen på ett eller annat sätt kan knytas till detta kollektiv som uppfattas vara kriminellt. ${ }^{39}$ Straffrättens tidigare klart individfokuserade ansvar har alltså i sådana fall övergått i ett ansvar som härleds från ett kollektiv.

Vi kan inte heller på straffrättens område undgå att notera den accentuering av de grundläggande mänskliga rättigheterna som har skett särskilt efter det andra världskriget. Av en särskild betydelse för alla stater i Europa är den Europeiska människorättskonventionen. Vissa av människorättskonventionens - inklusive dess tilläggsprotokolls - bestämmelser har också lämnat tydliga spår i straffrättens allmänna läror. Den klaraste kopplingen mellan den europeiska människorättskonventionen och utformningen av de allmänna ansvarsreglerna inom straffrätten utgår från konventionens artikel 7, som ger uttryck för den straffrättsliga legalitetsprincipen. Men också andra artiklar har en betydelse i detta avseende. ${ }^{40}$

Vi kan också observera en internationell harmonisering - eller t.o.m. en unifiering - av straffrättens allmänna läror, vars främst grund är en önskan att uppnå en

också Kyvsgaard (1995), s 120-126. Vagn Greve anser att de socialrättsliga tendenserna inom straffrätten kulminerade redan på 1930-talet. Greve (1999), s 12.

${ }^{36}$ Ett tydligt exempel på detta är beslutet att kriminalisera bara kundens gärning då könsköp kriminaliserades i Sverige. I propositionen konstaterades (Prop. 1997/98:55, Kvinnofrid): Prostitutionsutredningens förslag att kriminalisera såväl köpare som säljare har mötts av en omfattande kritik från så gott som samtliga remissinstanser. Även regeringen gör den bedömningen att även om prostitutionen som sådan inte är en önskvärd samhällsföreteelse så är det inte är rimligt att också kriminalisera den som, åtminstone i flertalet fall, är den svagare parten som utnyttjas av andra som vill tillfredsställa sin egen sexualdrift. Det är också viktigt för att motivera de prostituerade att söka hjälp för att komma bort från prostitutionen, att de inte känner att de riskerar någon form av påföljd för att de varit verksamma som prostituerade.

${ }^{37}$ Bl.a. då det gäller nödvärn har man diskuterat frågan om inte nödvärnsbestämmelsen borde utformas på ett annat sätt för att bättre svara mot kvinnointressen. Se Petter Asp: Nödvärnsrätten i kvinnoperspektiv. Lika inför Lagen. Rätten ur ett genusperspektiv. Uppsala, s 85-108.

${ }^{38}$ Gorm Toftegaard Nielsen, Asbjörn Strandbakken och Per Ole Träskman: Om selskabsansvar i Norden. NTfK 2003, s 1-27

${ }^{39}$ Se t.ex. EU:s initiativ (gemensam åtgärd) att göra deltagandet i en kriminell organisation i Europeiska unionens medlemsländer till ett brott 21 december 1998 (EGT 98/L 351/01). Se också Betänkande av Kommitten om straffansvar för organiserad brottslighet, m.m. SOU 2000:88, Organiserad brottslighet, hets mot folkgrupp, hets mot homosexuella, m.m. - straffansvarets räckvidd

${ }^{40}$ Särskilt Europakonventionens art. 3, 8 och 10 kan nämnas. Se också Ståle Eskeland: Straffrätten och de internationella mänskliga rättigheterna. Dag Victor (red.): Varning för straff. Om vådan av den nyttiga straffrätten. Stockholm 1995, s190-205. 
gemensam strafflagstiftning. En sådan strävan har varit en mycket viktig drivkraft för det nordiska straffrättssamarbetet, ${ }^{41}$ och också för det internationella samarbete som utförts inom ramen för FN respektive Europarådet. Flera av de åtgärder inom straffrättens område som vidtagits inom EU motiveras explicit med hänvisning till behovet av en gemensam straffrättslig reglering. ${ }^{42}$

Slutligen kan vi observera skäl som bygger på processekonomiska hänsyn och hänsyn till kravet på effektivitet. Straffrättens allmänna läror skall inte vara så komplicerade att utdömande av straffansvar inte kan ske utan en komplicerad rättegång, eller bara i ett fåtal av alla faktiska fall på grund av att beviskravet "ställt utom rimligt tvivel" inte alls eller bara svårligen kan uppnås i praktiken. ${ }^{43}$

\section{Konkretisering: Hur har de allmänna lärorna förändrat sig? Några exempel} Man kan säga att straffrättens grundläggande systematik bygger på begreppen "mänsklig gärning" 44 och "skuld". 45 Gärningsbegreppet - både i dess positiva variant (handling) och i dess negativa variant (underlåtenhet) - har ägnats otaliga analyser $\mathrm{i}$ den straffrättsvetenskapliga forskningen. ${ }^{46}$ Man kan också

\footnotetext{
${ }^{41}$ Nordiska straffrättskommitten, som tillsattes 1960 och som upphörde att fungera i början av 1990-talet, behandlade i fyra utredningar frågor som faller inom straffrättens allmänna läror. Den första av dessa utredningar gällde frågan om preskription (se Nordisk utredningsserie 1967:15), den andra straffmätning (se Nordisk utredningsserie 1984:2), den tredje straffansvar för juridiska personer (betänkande om företagsböter ingår i Nordisk utredningsserie 1986:2) och den fjärde frågan om straffrättslig jurisdiktion (se Nordisk utredningsserie 1992:17). Det måste konstateras att dessa betänkanden sällan ledde till en harmonisering av lagstiftningen inom Norden.

${ }^{42}$ T.ex. Corpus Juris-förslaget. Se Mireille Delmas-Marty: Corpus Juris introducing penal provisions for the purpose of the financial interests of the European Union. Paris 1997. Ett mycket gott exempel på hur man alltid bör beakta den europeiska dimensionen också då det gäller att beskriva bestämmelserna inom straffrättens allmänna läror finns i Vagn Greves straffrättslärobok "Det strafferetlige ansvar" (Greve [1999]). I den finns det under respektive avsnitt alltid också en beskrivning av EU-rätt. Beträffande EU-straffrätten mer generellt, se t.ex. Petter Asp: EU \& straffrätten. Studier rörande den europeiska integrationens betydelse för den svenska straffrätten. Uppsala 2002 och Thomas Elholm: EU-svig. En studie i dansk strafferet. København 2003.

${ }^{43}$ Ett exempel utgörs av det sätt varigenom man löst problemet med uppsåtsbedömningen vid vissa sexualbrott mot barn och unga. En kompletterande regel anger att straffansvar för sexuella handlingar mot barn och unga inte förutsätter att gärningsmannen insåg att offret var under en viss ålder. Det räcker att gärningsmannen hade skälig anledning anta detta. Se t.ex. den svenska bestämmelsen i BrB 6 kap. $11 \S$. Rättsliga presumtioner formuleras vanligen för att underlätta bevisningen. Frågan om sådana presumtioners förenlighet med Europakonventionen förbigås här.

44 "Brottet består alltid i mänskliga gärningar, inte i t.ex. tillstånd eller egenskaper varöver man inte har kontroll." Jareborg (2001), s 127.

45 "Straf forudsætter begrebsmæssigt, at personen bliver klandret for en lovstridig handling. Det er derfor en alment accepteret retlig grundsætning at strafansvar kræver personlig skyld (nulla poena sine culpa). Greve (1999) s 193. "Culpabegreppet är straffrättsdogmatikens mest centrala begrepp." Jareborg (2001), s 204.

${ }^{46}$ Se Christoffer Wong: Criminal Act, Criminal Jurisdiction and Criminal Justice. (Manuskript). Lund 2003, s. 171 och där anförda källor.
} 
konstatera att dessa grundläggande frågor - om vad som avses med en handling respektive en underlåtenhet - vanligen helt har överlämnats till den rättsvetenskapliga forskningen ${ }^{47}$ och till rättspraxis. ${ }^{48} \mathrm{I}$ detta avseende är det dock intressant att notera att man numera intagit en särskild bestämmelse i den finska strafflagen som gäller straffansvar för brott genom underlåtenhet. Denna bestämmelse bygger närmast på den konstruktion av straffansvar för underlåtenhet som förutsätter en särskild rättslig plikt att handla ("rättspliktsteorin"). ${ }^{49}$ Denna traditionella form för fastställande av straffansvar för underlåtenhet har allt mera i de nordiska länderna, särskilt i Sverige, fått vika för en ansvarskonstruktion som bygger på den s.k. garantläran. ${ }^{50}$

Bestämmelserna om straffrättslig jurisdiktion har en speciell karaktär inom straffrättens läror. Bestämmelserna ligger inom gränsområdet mellan folkrätten och straffrätten. ${ }^{51}$ Vissa av bestämmelserna har därtill en mer processuell än straffrättslig karaktär. ${ }^{52}$ Bestämmelserna har en dubbelfunktion: de anger samtidigt tillämpningsområdet för den nationella straffrätten (t.ex. vilka brott skall föranleda straffansvar enligt svensk straffrätt?) och brottmålsdomstolarnas internationella behörighet (alltså t.ex. över vilka brott har de svenska domstolarna domsmakt?). ${ }^{53}$

\footnotetext{
${ }^{47}$ I detta sammanhang är det skäl att särskilt nämna den doktrin kring gärningskontroll och gärningsculpa som Nils Jareborg utvecklat bl.a. i sina straffrättsläroböcker. Se t.ex. Jareborg (2001), s 203253. Betydelsen av detta har bl.a. framhävts av Kimmo Nuotio i en omfattande bokanmälan i NTfK 1997, s. 60-70.

${ }^{48} \mathrm{Jag}$ beklagar att jag i denna granskning inte har hänvisningar till utvecklingen på Island. Såsom så ofta ställer bristande språkkunskap hinder för en fullständigare granskning.

${ }^{49}$ Bestämmelsen (SL 3 kap. $3 \S$ enl.förf. 13.6.2003/515) har följande lydelse: Underlåtenhet är straffbar om detta uttryckligen anges i brottsbeskrivningen. Underlåtenhet är straffbar också om gärningsmannen har underlåtit att förhindra en följd som omfattas av en brottsbeskrivning, trots att gärningsmannen har haft en särskild rättslig skyldighet att förhindra följden. Skyldigheten kan grunda sig på 1) en tjänst, befattning eller ställning, 2) förhållandet mellan gärningsman och offer, 3) ett åtagande eller avtal, 4) gärningsmannens faroframkallande verksamhet, eller 5) någon annan därmed jämförbar orsak. Tapio Lappi-Seppälä menar dock att bestämmelsen också kan inordnas i ett system som bygger på garantläran. Tapio Lappi-Seppälä: Rikosoikeuden yleisiä oppeja koskeva uudistus I. Lakimies 2003, s 751-788.

${ }^{50}$ Se Jareborg (2001), s 184-202 samt Helen Örnemark Hansen: Bidragsbedrägeri. Stockholm 1995, 58-93.

${ }^{51}$ Wong (2004), s 23-52.

${ }^{52}$ Det kan diskuteras om de centrala jurisdiktionsbestämmelserna överhuvudtaget är materiellt straffrättsliga. Se Christoffer Wong (2004), s 56-62. Min egen uppfattning är att de flesta av bestämmelserna ingår i den materiella straffrätten.

${ }^{53}$ Notera formuleringen av de svenska bestämmelserna i BrB 2 kap. 1 § respektive 2 §: "För brott som begåtts här i riket dömes efter svensk lag och vid svensk domstol...", respektive "För brott som begåtts utom riket dömes efter svensk lag och vid svensk domstol ...". Se närmare Betänkande av Internationella straffrättsutredningen. SOU 2002:98. Internationella brott och svensk jurisdiktion. Del I, s 91-92.
} 
Jurisdiktionsbestämmelserna hör numera till de straffrättsbestämmelser som oftast blir förändrade och kompletterade. Detta beror vanligen på att en ny straffrättslig konvention - eller under senare tid någon ny EU-rättslig norm förutsätter att de nationella jurisdiktionsbestämmelserna revideras. Ofta handlar det om utvidgad jurisdiktion, särskilt med stöd av universalitetsprincipen ${ }^{54}$ Under årens lopp har antalet brott som underlyder jurisdiktionen för en stat med stöd av universalitetsprincipen ökat markant. Också i övrigt förefaller det finnas en stark politisk vilja att i mycket stor (eller t.o.m. överdrivet stor) omfattning innefatta också brott utomlands inom den egna straffrättsliga jurisdiktionen. Bl.a. den svenska bestämmelsen om att Sverige alltid har jurisdiktion över sådant brott utomlands som såsom lindrigaste straff enligt svensk lag har fängelse $\mathrm{i}$ fyra år eller däröver (BrB 2 kap.3 $§$ p.7) kan med fog kritiseras bl.a. utgående från folkrättsliga synpunkter. Detta har också skett i Nordiska straffrättskommitténs betänkande om straffrättslig jurisdiktion - ett betänkande som tyvärr inte fått den genomslagskraft i de nationella strafflagarna i Norden som det hade förtjänat. ${ }^{55}$

Utmärkande för den straffrättsliga jurisdiktion som bygger på universalitetsprincipen är särskilt att kravet på dubbel straffbarhet inte gäller. Detta krav kan ses som en viktig rättssäkerhetsgaranti, varför undantagen från kravet bör vara mycket väl motiverade. ${ }^{56}$ Också i detta fall kan man se en politisk tendens att markera egna nationella värderingar om vad som alltid skall kunna bestraffas genom att explicit avskaffa kravet på dubbel straffbarhet. Ett tydligt svenskt exempel på detta är brottet könsstympning. ${ }^{57}$

Bestämmelserna om vem som kan begå ett brott (ansvarigt brottssubjekt) och hur straffansvaret skall fördelas mellan två eller flera personer som begår brott tillsammans (medverkan $i$ brott) har förändrats betydligt. Ett straffansvar för juridiska personer har införts i Danmark, Finland och Norge. ${ }^{58}$ I Sverige har alla försök att införa ett straffansvar för bolag och andra juridiska personer tills

\footnotetext{
${ }^{54}$ Se Betänkande av Internationella straffrättsutredningen. SOU 2002:98, s 82-83 och 84-89.

${ }^{55}$ Se Nord 1992:17, s 119: "Nordiska straffrättskommitten anser således att t.ex. den omfattande jurisdiktion som svensk domstol har över brott utomlands med stöd av BrB 2:3 punkt 7 inte är befogad."

${ }^{56}$ Se Per Ole Träskman; Should we Take the Condition of Double Criminality Seriously? NTfK 1989, s 135-155. Karin Cornils: Zur Regelung des räumlichen Geltungsbereichs im finnischen Straqfgesetzentwurf. Raimo Lahti \& Kimmo Nuotio (Ed.): Criminal Law Theory in Transition: Finnish and Comparative Perspectives. Helsinki 1992, s 571-586.

${ }^{57}$ Lag (1982:316) med förbud mot könsstympning av kvinnor. Enligt 3 § i denna lag kan brottet bestraffas vid svensk domstol då det begåtts utomlands också om brottsbalken 2 kap. 2 § (jurisdiktion med stöd av den aktiva personalitetsprincipen) eller $3 \S$ (bl.a. flaggprincipen) inte är tillämplig. Se Lena Holmqvist m.fl. Brottsbalken. En kommentar. Del I (1-12 kap.) brotten mot person och förmögenhetsbrotten m.m. Studentutgåva 3. Stockholm 2002, s. 2:25.

${ }^{58}$ En översikt finns i Gorm Toftegaard Nielsen, Asbjörn Strandbakken och Per Ole Träskman: Om selskabsansvar i Norden. NTfK 2003, s 1-27.
} 
vidare strandat. ${ }^{59}$ I stället har man nöjt sig med att ta i bruk en särskild sanktion som riktas mot juridiska personer, företagsbot. Denna sanktion betecknas emellertid inte som straff eller ens som en straffrättslig påföljd, utan som en särskild rättsverkan av brott. ${ }^{60}$

Diskussionen om utformningen av bestämmelserna om medverkan i brott har framför allt gällt frågan om gränsdragningen mellan gärningsmannaskap och medhjälp och särskilt den form av medgärningsmannaskap som har betecknats som "utvidgat". Frågan om det utvidgade gärningsmannaskapet har debatterats särskilt i Sverige, där det har framförts att man genom att ersätta den tidigare beskrivningen för medgärningsmannaskap - "gemensamt och i samråd" mot beskrivningen "tillsammans och i samförstånd" har infört ett kollektivt straffansvar som kränker all traditionell uppfattning om rättssäkerhet. Suzanne Wennberg har anfört att:

I Sverige har emellertid medgärningsmannaskapet på senare år kommit att tillämpas på ett sätt som inger farhågor för rättssäkerheten. Man tillämpar ett utvidgat medgärningsmannaskap och grundar detta på så svaga grunder som att vederbörande medgärningsman måste ha varit införstådd med den brottsliga verksamheten, som sedan utförts av de andra medgärningsmännen. När flera personer varit närvarande på brottsplatsen och man inte riktigt vet vem som gjort vad respektive vem som stått helt utanför verksamheten, får man på så sett ett redskap med vars hjälp samtliga kan fällas till ansvar. $[\ldots] \mathrm{Om}$ inte ens åklagarens gärningsbeskrivning individualiserar vars och ens insats, får en tilltalad person inte reda på vad som läggs honom till last, utan samtliga tilltalade buntas ihop till en grupp som betraktas som brottssubjekt för gärningen. ${ }^{61}$

Den lägsta straffansvarsåldern är numera 15 år i alla nordiska länder. ${ }^{62}$ Samtidigt kan det konstaterats att förslag om att sänka straffansvarsåldern ofta har framställts med hänvisning till behovet av en sträng straffrättslig kontroll också av brottsliga gärningar som begås av barn. Detta förefaller vara fallet i alla nordiska länder, men sådana förslag har tills vidare avvisats. ${ }^{63} \mathrm{I}$ ett större internationellt perspektiv kan det konstateras att straffansvarsåldern varierar betydligt. I ett principiellt viktigt avgörande ( $\mathrm{T}$ och $\mathrm{V}$ mot Storbritannien, dom

\footnotetext{
${ }^{59}$ Se särskilt Företagsbrottsutredningens betänkande SOU 1997:127. Straffansvar för juridiska personer.

${ }^{60}$ Ulf Berg m.fl.: Brottsbalken. En kommentar. Kap. 25-38. Följdförfattningar. Fortlöpande komplettering, s. 36:57-36:64.

${ }^{61}$ Suzanne Wennberg: Tillsammans och i samförstånd - ett nytt begrepp för gärningsmannaskap. Förhandlingarna vid Det 36 nordiska juristmötet i Helsingfors 15-17 augusti 2002. Del I. Helsingfors, s. 613-638. Se också Erling Johannes Husabøs korreferat. Förhandlingarna vid Det 36 nordiska juristmötet i Helsingfors 15-17 augusti 2002. Del II. Helsingfors, s.287-294, samt de övriga inlägg som gjordes vid juristmötet, ibidem, s. 294-299.

${ }^{62}$ Anette Strand Westerlund: Barnets straffrättsliga skuld. Manuskript för avläggande av juris licentiatexamen i straffrätt. Lund 2003, s 69-75. Det bör noteras att den svenska regleringen egentligen inte innebär att barn under 15 år inte kan begå brott - men de kan inte dömas till straff eller annan straffrättslig påföljd (BrB 1 kap. 6 §).

${ }^{63}$ Se t.ex. för Finlands del Lappi-Seppälä (2003), s 769-770 och för Norges del NOU 2002:4, s 228.
} 
16.12.1999) fastslog Europadomstolen att det inte kunde anses strida mot Europakonventionens artikel 3 att två barn som bara var 10 år vid brottets begående dömdes till straffansvar och att påföljden bestämdes till tidsobestämt frihetsberövande. Domstolen förklarade att straffmyndighetsåldern varierar mellan olika länder på så sätt att det inte finns någon gemensam europeisk standard på området, och att det inte heller kan anses utgöra en kränkning av Europakonventionen att barn ådöms tidsobestämda straff. ${ }^{64} \mathrm{Ur}$ en humanitär synpunkt kan detta avgörande av Europadomstolen bara beklagas.

Regleringen om straffansvar för brottslig gärning som har begåtts av en psykiskt störd person bygger vanligen på en tillräknelighetslära. ${ }^{65}$ Undantag är Sverige där också en brott som har begåtts av en person som vid gärningsögonblicket led av en allvarlig psykisk störning kan föranleda straffansvar. Men en sådan person kan inte dömas till fängelse. ${ }^{66}$ Denna reglering i Sverige bygger på uppfattningar som ursprungligen fördes fram inom den kriminalpolitiska riktning som byggde på tanken om samhällsskydd. I sitt slutbetänkande, Skyddslag (SOU 1956:55), föreslog Strafflagsberedningen bl.a. att straffriförklaringarna på grund av bristande tillräknelighet skulle avskaffas. Beredningen ansåg att tillräknelighetsläran hade spelat ut sin roll. I stället skulle de psykiskt störda lagöverträdarna - om vårdbehov förelåg - dömas till vård på sinnessjukhus eller i öppen psykiatrisk vård. Individualpreventiva skäl skulle vara avgörande för om sådan vård kom till stånd. Som ett resultat av dessa förslag avskaffades tillräknelighetsläran vid Brottsbalkens införande ${ }^{67}$ Denna i ett rättsjämförande perspektiv märkliga reglering har nu föreslagits bli ändrad genom ett återinförande av tillräknelighetsbegreppet i svensk rätt. ${ }^{68}$

Bestämmelserna om förberedelse, stämpling och försök är inte identiska i de nordiska länderna. Särskilt skall noteras att den danska regleringen om försök (straffeloven § 21) ger möjlighet att straffa försökshandlingar i en mycket vid omfattning. De krav som ställs på försökets objektiva sida är mycket små. Gränsen mellan det straffbara och det straffria beror därför i allt väsentligt på gärningspersonens subjektiva inställning. ${ }^{69} \mathrm{I}$ andra nordiska länder inträder straffansvar för försök $\mathrm{i}$ ett senare skede av gärningens utveckling mot ett fullbordat brott. Straffansvar kan emellertid i vissa fall följa redan tidigare med stöd av bestämmelser om förberedelse eller stämpling. Vid en rättsjämförande granskning finner man således att denna del av läran om straffansvar för brott är

\footnotetext{
${ }^{64}$ Hans Danelius: Europadomstolens domar - fjärde kvartalet 1999. SvJT 2000, s 93-94.

${ }^{65}$ Betänkande av straffansvarsutredningen. SOU 1996:185. Del II, s 255-304.

${ }^{66}$ Se Brottsbalken 30 kap. 6 \$.

${ }^{67}$ Betänkande av Psykansvarskommitten. SOU 2002:3. Psykisk störning, brott och ansvar, s 166.

${ }^{68}$ Betänkande av Psykansvarskommitten. SOU 2002:3. Psykisk störning, brott och ansvar.

${ }^{69}$ Vagn Greve m.fl: Kommenteret straffelov. Almindelig del. 7. omarbejdede udgave. København 2001, s.191.
} 
föränderlig, genom att bestämmelserna i skilda stater skiljer sig från varandra. ${ }^{70}$ $\AA$ andra sidan finner man, vid en nationell granskning av bestämmelserna i en viss stat, att dessa bibehållits rätt oförändrade.

Frågan om hur uppsåt och hur oaktsamhet skall bestämmas hör till evighetsfrågorna inom den straffrättsliga ansvarsläran. Frågan diskuterades bl.a. livligt vid det Nordiska juristmötet $1960 .{ }^{71}$ En av kärnpunkterna i diskussionen har varit om uppsåt skall byggas på en viljeteori eller på en insiktsteori. ${ }^{72}$ Frågan om bestämmande av uppsåt och oaktsamhet har numera i lösts i Finland genom att i strafflagen inta uttryckliga bestämmelser om vad dessa begrepp uttrycker. ${ }^{73}$ Också i Norge föreslås en explicit lagreglering av vad som avses med uppsåt och vad med oaktsamhet. ${ }^{74}$ I Sverige har man tills vidare förkastat förslagen om inta en legal definition av uppsåt och oaktsamhet i Brottsbalken. Men uppsåt diskuteras livligt i Sverige. Den aktuella debatten är en följd av en HD-dom som förkastade (och förmodligen utdömde) konstruktionen eventuellt uppsåt (dolus eventualis) med hypotetiskt prov. ${ }^{75}$ Domen kom dock till efter omröstning där de fem justitierådens röster fördelade sig 2-2-1. Två av domarna avgjorde fallet med tillämpning av en form för likgiltighetsuppsåt, och detta blev den avgörande meningen. Två avgjorde fallet med tillämpning av ett sannolikhetsuppsåt, medan en önskade tillämpa eventuellt uppsåt med hypotetiskt prov. ${ }^{76}$ Man kan konstatera att domen i stället för att skapa säkerhet om vad som gäller skapade en stor förvirring.

\footnotetext{
${ }^{70}$ Betänkande av straffansvarsutredningen. SOU 1996:185. Straffansvarets gränser. Del II, s 207-213.

${ }^{71}$ Forsett och rettvillfarelse i strafferetten. Forhandlingarna å det tjugoandra Nordiska Juristmötet i Reykjavik 1960. København 1963. Se också Betänkande av Straffansvarsutredningen SOU 1996:185. Del II, s 13-102.

${ }^{72}$ Se också Knud Waaben: Strafferettens almindelige del I Ansvarslæren. 3, reviderede udgave. København 1993, s139-140.

${ }^{73}$ Se den finska strafflagen 3 kap. 6 § och 7 §: Gärningsmannen har uppsåtligen orsakat en följd som omfattas av en brottsbeskrivning, om han eller hon har avsett att orsaka följden eller ansett följden vara säker eller övervägande sannolik. Följden har likaså orsakats uppsåtligen, om gärningsmannen ansett att den med säkerhet har samband med den följd han eller hon avsett. [...] En gärningsmans förfarande är oaktsamt, om gärningsmannen åsidosätter den aktsamhetsplikt som han eller hon under de rådande omständigheterna har, trots att han eller hon hade kunnat rätta sig efter den (oaktsamhet). Frågan om oaktsamheten skall anses vara grov (grov oaktsamhet) avgörs utifrån en helhetsbedömning. Vid bedömningen skall beaktas hur betydande den åsidosatta aktsamhetsplikten är, hur viktiga de äventyrade intressena och hur sannolik kränkningen är, hur medveten gärningsmannen är om att han eller hon tar en risk samt övriga omständigheter som har samband med gärningen och gärningsmannen. För en gärning som snarare grundar sig på olyckshändelse än på oaktsamhet bestraffas gärningsmannen inte.

${ }^{74}$ Se förslag till § 3-9 respektive 3-10, NOU 2002:4, s 476.

${ }^{75}$ NJA 2002 s 449.

${ }^{76}$ Petter Asp, Per Ole Träskman, Håkan Westin och Josef Zila. Uppsåtets nedre gräns. Juridisk Tidskrift 2002-03, s 613-639.
} 
Då det gäller lösningen av frågor som kan involvera uppsåts- och oaktsamhetsbedömningar kan man lätt konstatera att det inte finns enighet om den riktiga lösningen. Detta gäller bl.a. konsekvenserna av villfarelse och av felslag, alltså aberratio ictus. Norsk rätt innehåller både en bestämmelse om faktavillfarelse (Straffeloven $\S 42$ ) och om rättsvillfarelse (§ 57), dansk rätt innehåller bara en bestämmelse som möjliggör lindrigare straff vid rättsvillvarelse (Straffeloven $\S$ 84), medan betydelsen av andra former av villfarelse har överlämnats till att bli löst av praxis och rättsvetenskap. ${ }^{77}$ I Sverige infördes en särskild bestämmelse om straffrättsvillvarelse genom en lagändring 1994 (Brottsbalken 24 kap. 9 \& [lag 1994:458]. Lösningen av frågan om vilken verkan faktisk villfarelse och oegentlig rättsvillfarelse skall ha, ankommer i Sverige fortfarande på praxis och rättsvetenskap. ${ }^{78} \mathrm{I}$ den finska strafflagen ingår numera en bestämmelse om rekvisitvillfarelse (faktavillfarelse), förbudsvillfarelse (rättsvillfarelse) och villfarelse om en ansvarsfriande omständighet. ${ }^{79}$ Den största oenigheten i alla nämnda nordiska länder finns om en rättsvillfarelse skall föranleda straffrihet, ${ }^{80}$ och när det egentligen föreligger en sådan oegentlig rättsvillfarelse som bör bedömas som bristande uppsåt. ${ }^{81}$

Oenigheten beträffande bedömningen av aberratio ictus gäller framför allt om ett felslag skall bedömas som en oaktsamhetsgärning, eller om gärningsmannens uppsåt skall anses vara oförändrat trots att gärningen träffade fel objekt. ${ }^{82}$

Då det gäller grunder som utesluter rättsstridighet och grunder som utesluter skuld kan man notera att sådana grunder som tidigare varit oreglerade i lag numera har lagreglerats i vissa fall. I Sverige intogs t.ex. bestämmelser om samtycke i Brottsbalken år $1994 .^{83}$ Men många av dessa rättfärdigande eller ursäktande grunder gäller fortfarande bara med stöd av rättspraxis. Beträffande den närmare utformningen av grunderna kan man konstatera att särskilt frågan om när nödvärn utesluter gärningens rättsstridighet har diskuterats. Diskussionen har både gällt frågan om när en nödvärnshandlig inte skall bedömas ha varit uppenbart oförsvarlig (ofta i samband med försvar med användande av

\footnotetext{
${ }^{77}$ Gorm Toftegaard Nielsen: Strafferet I. Ansvaret. København 2001, s 92-103; Greve (1999), s 230238.

${ }_{78}^{73}$ Jareborg (2001), s 352-355.

${ }^{79}$ Den finska strafflagen 4 kap. $1-3 \S \S$.

${ }^{80}$ Se diskussionen i Toftegaard Nielsen (2001), s. 92-101 samt Greve (1999), s 230-235.

${ }^{81}$ Se Greve (1999), s 236-238. Notera att Jareborg [(2001), s 355] anser att en uppdelning av villfarelse i de tre gängse formerna är meningslös.

${ }^{82}$ Se för en aktuell diskussion Petter Asp: Om uppsåtstäckning vid aberratio ictus. Juridisk Tidskrift 2001/2002, s 610-621 och Peter Borgström \& Samuel Cavallin: Om uppsåtstäckning och rättsfallet RH 2001:2. Juridisk Tidskrift 2002/2003, s 717-734.

${ }^{83}$ BrB 24 kap. 7 \& (lag 1994:458).
} 
skjutvapen), ${ }^{84}$ och när det skall vara tillåtet att använda nödvärn mot ett presumerat angrepp, alltså ett angrepp som kan förväntas komma först senare. ${ }^{85}$

I Norden har man av tradition var ganska tveksam till att införa regler som innebär att möjligheten att lagföra ett brott aldrig upphör. ${ }^{86}$ Den senaste internationella utvecklingen har emellertid inneburit att det numera finns ett behov av att avskaffa alla preskriptionstider då det gäller vissa internationella brott. Bl.a. de brott som omfattas av den Internationella brottmålsdomstolens behörighet (folkmord, brott mot mänskligheten och krigsförbrytelser) skall enligt den bakomliggande Romkonventionen undantas från de vanliga reglerna om preskription.

Uppfattningarna om hur straffmätningen och påföljdsvalet skall lagregleras går i sär. Enligt en uppfattning skall lagregleringen i detta fall vara minimal och besluten överlämnas till domaren för att bli tagna av honom enligt hans "inre övertygelse". Enligt en annan uppfattning krävs det här precisa regler intagna i lag, bl.a. för att säkerställa en enhetlig rättspraxis. Det finns också en grundläggande oenighet om vilken straffideologi, vilka "straffteorier" som skall styra staffmätningen och påföljdsvalet. Är det individualpreventionen, allmänpreventionen eller ett krav på rättvis proportionalitet som skall vara styrande?

Dessa frågor kan inte behandlas utförligare i denna artikel. ${ }^{87}$ Det bör dock noteras att det finns detaljerade bestämmelser om straffmätning och påföljdsval i Finland ${ }^{88}$ och i Sverige, ${ }^{89}$ medan bestämmelserna i Danmark ${ }^{90}$ och i Norge ${ }^{91}$ är tämligen generella och intetsägande. ${ }^{92}$

\footnotetext{
${ }^{84}$ Se t.ex. Jareborg (2001), 259-263.

${ }^{85}$ Se Petter Asp: Nödvärnsrätten i kvinnoperspektiv. Lika inför Lagen. Rätten ur ett genusperspektiv. Uppsala, s 85-108.

${ }^{86}$ Se Betänkande av Internationella straffrättsutredningen. SOU 2002:98, s 274-275 och 332-333.

${ }^{87}$ Frågan har ofta utretts också internationellt, se t.ex. Council of Europe. Sentencing. Strasbourg 1974; Council of Europe. Disparities in Sentencing. Cause and Solutions. Strasbourg 1989; Council of Europe. Consistency in Sentencing. Recommendations No. R (92) 17. Strasborg 1993. Se också Straffelovrådets betænkning om straffastsættelse og strafferammer. Betænkning nr. 1424

${ }^{88}$ Strafflagen 6 kap.

${ }^{89}$ Brottsbalken särskilt 29 och 30 kap.

${ }^{90}$ Straffeloven 10. kapitel. Straffens fastsaettelse.

${ }^{91}$ Beträffande Norge, se Johs. Andenaes: Alminnelig strafferett. 3. utgave. Oslo 1989, s 394-408.

${ }^{92}$ Bland den omfattande litteraturen om straffmätning kan nämnas Nils Jareborg \& Josef Zila: Straffrättens påföljdslära. Stockholm 2000; Eva Stenborre: Påföljdsbestämningen i Sverige och straffutmålingen i Norge. Med en studie av rättsfall från Högsta domstolen och Höyesterett. Lund 2003; Andrew von Hirsch: Proportionalitet och straffbestämning. Uppsala 2001; Vagn Greve: Straffene. 2. udgave. Koebenhavn 2002; Gorm Toftegaard Nielsen: Strafferet 2. Sanktionerne. Koebenhavn 2002; Tapio Lappi-Seppälä: Rikosten seuraamukset. Porvoo 2000; Rasmus H. Wandall: Sentencing to Imprisonment. A Socio-Legal Study of Decisions to Incarcerate in Criminal Cases in Danish County Courts. Ph.D.-dissertation submitted for the defence to the Faculty of Law, University of Copenhagen. 2004.
} 


\section{Avslutning: Och vad nu...?}

Att betrakta straffrättens allmänna läror kan inte förliknas vid att betrakta ett stillastående vatten. Det finns trots allt en viss rörelse. Men det kan inte heller förliknas vid att betrakta en häftigt brusande vårflod. Rörelserna är inte så stora eller så snabba.

Men vad kommer nu att ske - vilka förändringar kan väntas? Med stor sannolikhet kan vi förvänta en ökad internationalisering, harmonisering eller t.o.m. unifiering. Ännu en gång är det befogat att hänvisa till utvecklingen inom EU och kanske särskilt försöken att skapa den gemensamma strafflagen och straffprocesslagen "Corpus Juris". I det senaste förslaget till Corpus Juris ingick bl.a. förslag till bestämmelser om följande delar av de allmänna lärorna: Mens rea (uppsåt och oaktsamhet), faktisk villfarelse och rättsvillfarelse, medverkan i brott, försök, straffrättsligt husbondeansvar, straffansvar för juridisk person, straffmätning, grunder som utesluter rättsstridighet, grunder som utesluter skuld, och straff för brott i konkurrens. Avsikten är att dessa bestämmelser skall vara gemensamma inom hela EU-området då det gäller i lagförslaget avsedda brott.

Det betyder att det inte blir mycket kvar att bestämma för den nationella lagstiftaren. Vi måste lära oss att leva med faktum: Vad som finns i dag är en gemensam europeisk kriminalpolitik och den begränsar betydligt utrymmen för nationella initiativ - också då det gäller de allmänna lärorna. ${ }^{93}$

Adress:

Lunds Universitet

Box 117

SE-22100 Lund

E-post: per_ole.traskman@jur.lu.se

\footnotetext{
${ }^{93}$ Per Ole Träskman: En gemensam europeisk strafflag begränsar nationell kriminalpolitik. BRÅ-Rapport 1999:9. 8 reflektioner om kriminalpolitik; Per Ole Träskman: Straffrättsligt samarbete i EU:s tredje pelare något att sträva efter? Förhandlingarna vid Det 36 nordiska juristmötet i Helsingfors 15-17 augusti 2002. Del II. Helsingfors, s 462-469.
} 